\title{
Cotidiano
}

Alexandre Freitas Marchiori'

Carla de Almeida Aguiar França²

\section{Práticas e articulações pedagógicas na educação infantil: contribuições ao processo de desenvolvimento de uma criança com autismo}

\begin{abstract}
Resumo: O presente artigo está pautado no reconhecimento da integralidade do sujeito e da necessidade de um trabalho pedagógico que amplie as possibilidades formativas da criança na educação infantil. O objeto de estudo é o autismo e as possibilidades de desenvolvimento de Suely ${ }^{3}$ na relação com os pares e adultos do Centro Municipal de Educação Infantil (CMEI). A metodologia corresponde a um estudo de caso etnográfico, com pesquisa participante, empregado para acompanhar as práticas pedagógicas em um CMEl do município de Vitória, desenvolvidas com uma turma do Grupo 4/5, crianças de 04 e 05 anos. $O$ sujeito da pesquisa corresponde a uma criança diagnosticada clinicamente com autismo. A pesquisa compreendeu o período de 02 anos (2015-2016). Como propõe Vygotsky (2005, 2006, 2007), a formação da identidade perpassa as relações sociais, estão presentes nas interações com o outro, na apropriação da cultura e no desenvolvimento da linguagem. Os objetivos da pesquisa buscaram traçar perspectivas de trabalho pedagógico para auxiliar no processo de desenvolvimento de uma criança com autismo, atendida na educação infantil. O trabalho realizado ao longo de 2015 esteve organizado a partir das interações e brincadeiras. Em 2016, buscou romper com possíveis limitações advindas do Transtorno do Espectro do Autismo (TEA), numa abordagem colaborativa. Os aprendizados que podem ser destacados na formação de Suely foram o desenvolvimento da linguagem oral, uma vez que capacita o sujeito a interagir com os demais e se apropriar de signos e produzir novos significados, a apropriação dos usos da leitura e da escrita, das capacidades de interação social, de expressão artística e estética e autonomia nas escolhas necessárias no cotidiano da instituição.
\end{abstract}

Palavras-chave: Autismo. Educação Inclusiva. Educação Física. Educação Infantil.

\section{Pedagogical practices and articulations in child rearing: contributions to the development process of a child with autism}

Abstract: The present article is based on the recognition of the integrality of the subject and the necessity of a pedagogical work that amplifies the formative possibilities of the child in the child rearing. The object of study is the autism and the possibilities of development of Suely in the relation with the pairs and adults of the Municipal Child Rearing Center (MCRC). The methodology corresponds to a case study, used to follow the pedagogical practices in a MCRC of the city of Vitória, developed with a class of Group 4/5, children from 04 to 05 years. The subject of the research corresponds to a student diagnosed clinically with autism. The research period comprised 10 months (March to December) of the year 2016. As Vygotsky $(2005,2006,2007)$ proposes, the formation of identity permeates social relations, are present in interactions with each other, in the appropriation of culture and In language development. The objectives of the research sought to outline pedagogical work perspectives to aid in the development process of a child with autism, attended in early childhood education.

1 Mestre em Educação, Prefeitura Municipal de Vitória, e-mail: alexandremarchiori@hotmail.com.

2 Professora Especialista, Prefeitura Municipal de Vitória, e-mail: carlaaguiar13@yahoo.com.br.

3Nome fictício para preservar sua identidade. 
The work carried out during 2016 sought to break with possible limitations arising from Autism Spectrum Disorder (ASD), in a preventive and proactive approach. The learning that can be highlighted in the formation of Suely was the development of oral language, since it enables the subject to interact with others and to appropriate signs and produce new meanings, appropriation of the uses of reading and writing, Social interaction, artistic expression and aesthetics and autonomy in the choices needed in the daily life of the institution.

Keywords: Autism. Inclusive education. Physical Education. Child Rearing.

\title{
Introdução
}

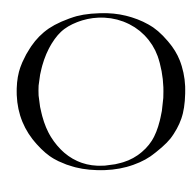

autismo, objeto de interesse deste estudo, possui particularidades que são prescritas em lei federal, como propõe a Lei 12764/2012:

\begin{abstract}
Art. 1o Esta Lei institui a Política Nacional de Proteção dos Direitos da Pessoa com Transtorno do Espectro Autista e estabelece diretrizes para sua consecução.

\10 Para os efeitos desta Lei, é considerada pessoa com transtorno do espectro autista aquela portadora de sindrome clinica caracterizada na forma dos seguintes incisos I ou II:

I - deficiência persistente e clinicamente significativa da comunicação e da interaşão sociais, manifestada por deficiência marcada de comunicasão verbal e não verbal usada para interação social; ausência de reciprocidade social; falência em desenvolver e manter relações apropriadas ao seu nível de desenvolvimento;

II - padrões restritivos e repetitivos de comportamentos, interesses e atividades, manifestados por comportamentos motores ou verbais estereotipados ou por comportamentos sensoriais incomuns; excessiva aderência a rotinas e padrões de comportamento ritualizados; interesses restritos e fixos.
\end{abstract}

Conforme a referida lei, a pessoa com Transtorno do Espectro Autista (TEA) é considerada pessoa com deficiência, exigindo-se a atenção integral às necessidades de saúde da pessoa com TEA, com objetivo de diagnóstico precoce, atendimento multiprofissional e acesso a medicamentos e nutrientes (Artigo $2^{\circ}$, inciso III).

Dentre os direitos da pessoa com TEA, é possível destacar o direito a uma vida digna, sua integridade física e moral, o livre desenvolvimento da personalidade, a segurança e o lazer, bem como o acesso à educação. Esta deve ocorrer em classes comuns de ensino regular, com acompanhamento especializado. 
Para Araújo e Lotufo Neto (2014, p. 68), a nova Classificação Americana para Transtornos Mentais (DSM-5) apresenta alguns paradigmas da psiquiatria e análise do comportamento. Segundo os autores:

A visão da psiquiatria traduzida através da psicopatologia segue o modelo médico instituído desde os tempos hipocráticos, nos quais o diagnóstico era fundamentalmente empírico. A observação, descrição e categorização de enfermidades que compartilham sinais e sintomas permite a formulação de diagnósticos que, por sua vez, auxiliam na identificação da causa de uma determinada patologia, na previsão de sua evolução e no planejamento terapêutico.

Essa percepção do autismo, uma visão médica ou clínica, necessita ser problematizada na atuação com criança com deficiência, uma vez que compreender o distúrbio e se apropriar dos conhecimentos sistematizados auxiliam o profissional na condução do processo de acompanhamento e intervenção com a criança. Todavia, como pontuam Araújo e Lotufo Neto (2014, p. 68) "o constructo teórico do Behaviorismo rejeita a ideia de que um comportamento tenha justificativa em si mesmo ou que possa ser analisado fora do contexto em que ocorre".

A DSM-5, segundo os autores supracitados, apresentam “os critérios para Deficiência Intelectual e enfatizaram que, além da avaliação cognitiva é fundamental avaliar a capacidade funcional adaptativa". Os Transtornos Globais do Desenvolvimento - TGD (Autismo, Síndromes de Asperger e Rett, Transtorno Desintegrativo da infância) foram absorvidos por um único diagnóstico denominado Transtornos do Espectro Autista, agrupados segundo o déficit na comunicação e interação social; bem como padrão de comportamento, interesses e atividades repetitivos e restritos. Concluem o artigo fazendo um alerta:

O DSM é um instrumento desenvolvido para ser aplicado por profissionais habilitados, com experiência clínica e sólido conhecimento da psicopatologia. [...] é preciso notar que o manual não deve ser usado como uma simples lista de sintomas para serem assinalados por indivíduos não habilitados, pois isso implicaria em falsos diagnósticos positivos (ARAÚJO; LOTUFO NETO, 2014P. 82).

No tocante à educação de pessoas com TEA, Vasques e Baptista (2014, p. 670) contribuem significativamente. No trabalho intitulado "Transtornos Globais do Desenvolvimento e Escolarização: conhecimento em perspectiva" discutem algumas possibilidades da educação inclusiva e estabelecem conceitos chaves para orientar as práticas com o público-alvo da educação especial. Segundo os autores, a pesquisa identificou que o fazer docente não tem sido objeto de estudo sistemático em grande parte dos trabalhos analisados. Quanto aos TGD, afirmam:

As deficiências e os TGD são descritos não só com alterações orgânicas estruturais ou funcionais, mas como decorrentes também das relações humanas, econômicas, sociais etc. $\mathrm{Na}$ constituição do sujeito como deficiente, deficitário, ou não, sublinha-se a força dos encontros, da cultura, das políticas como possibilitadoras ou limitadoras do humano (VASQUES; BAPTISTA, 2014, p. 671).

Os autores se debruçam sobre teses e dissertações na busca de indícios e pistas para compreender as práticas investigativas e as considerações produzidas ao longo da última década (2000-2012). Na 
categoria diagnóstico, avaliação e processos de identificação encontram duas perspectivas, sendo uma delas profícua a este estudo, a saber:

[...] Outro grupo de pesquisadores interroga os sistemas classificatórios e seus influxos nos processos de escolarização; o modelo médico e o esvaziamento do lugar e do professor em decorrência de uma leitura que considera os sujeitos com TGD como deficitários e inaptos, que hipervaloriza o conhecimento dos especialistas em detrimento do saber construído na experiência escolar (VASQUES; BAPTISTA, 2014, p. 675).

$\mathrm{Na}$ visão dos autores, há necessidade de "construir espaços de reconhecimento e valorização da singularidade, a fim de que a escola ocupe uma função constitutiva e terapêutica" (VASQUES; BAPTISTA, 2014, p. 676).

Pallarès e Paula (2012) apresentam um panorama do autismo nos últimos 70 anos, num diálogo especial com Leo Kanner e Hans Asperger. Segundo os autores, Kanner propôs como critérios de definição precoce do autismo, sendo:

Profundo isolamento para o contato com as pessoas, um desejo obsessivo de preservar a identidade, uma estreita relação com os objetos, a conservação de um rosto inteligente e bem planejadas e uma comunicação verbal prejudicada como manifestado pelo silêncio ou por um tipo de linguagem desprovida de intenção comunicativa. Em todos estes aspectos, em 1951 Kanner destacava como característica nuclear: a obsessão em manter a identidade, expressa pelo desejo de viver em um mundo estático, onde as mudanças não são aceitas (PALLARÈS E PAULA, 2012, p. 571).

Esses autores cientificam que Asperger também sistematizou um trabalho para diagnóstico e intervenção junto ao sujeito autista. Seus pacientes possuíam um padrão de conduta:

A falta de empatia, criatividade, incapacidade de fazer amigos, de linguagem pedante ou repetitivo, má comunicação não verbal, de juros excessiva em determinados temas e falta de destreza motora e má coordenação [...] Asperger não foi apenas um grande médico, mas era um fervoroso defensor da integração social e laboral de pessoas com as características que ele havia descrito. É notável que numa sociedade governada por ideias eugênicas da sociedade nazismo, Asperger destacara o valor social desses cidadãos, coincidindo com Kanner em sua abordagem humanista para o tratamento de pacientes (PALLARÈS E PAULA, 2012)

Segundo os autores, os estudos de Piaget destacam a participação ativa do sujeito. Essa ação desencadeia um processo de produção do conhecimento de si mesmo (PALLARÈS e PAULA, 2012, p. 577). Entretanto, essa ação não deve ser vista na sua singularidade, mas articulada nas interações sociais, nas relações do sujeito com a cultura e a linguagem. Tal perspectiva está fundamentada nos estudos da abordagem sócio histórica ou sócio interacionista da escola russa, com destaque para os estudos de Lev Vygotsky. Orrú (2010, p. 3) afirmar que:

$\mathrm{Na}$ perspectiva da abordagem histórico-cultural o professor contribui como um mediador na reconstituição e na melhora da vivência emocional de seu aluno para que seu ser, muitas vezes revelado em suas ações, transcenda as reações afetivas imediatas para outras mais duradouras. A Comunicação Suplementar Alternativa (CSA) foi utilizada como um mediador simbólico para auxiliar na construção da linguagem que traz a possibilidade de produção de significações, geradas na relação com o outro, em ambientes culturalmente contextualizados. Em relação às práticas pedagógicas oriundas da abordagem comportamental de Skinner que evidencia as limitações do autista, a abordagem histórico-cultural de Vigotsky trouxe à tona novas possibilidades 
pedagógicas no que diz respeito à constituição da linguagem por meio das relações sociais privilegiadas no ambiente escolar deste aluno numa perspectiva inclusiva e otimista de seu desenvolvimento cognitivo.

Segundo a autora, o termo autismo é utilizado para denominar comportamentos humanos que se centralizam em si mesmos e, conforme seus estudos, trata-se de uma disfunção orgânica e não um problema dos pais.

Orrú (2010, p. 5) argumenta que até 1989 dizia-se, estatisticamente, que a síndrome acometia crianças com idade inferior a 3 anos, com predominância de 4 crianças a cada 10 mil nascidas, numa proporção de a cada 4 casos confirmados, 3 correspondiam ao sexo masculino e 1 caso para o feminino. Em 2002, a incidência de autismo foi considerada de 1 em cada 175 nascimentos, sendo 4 meninos para 1 menina. Já em 2003 as estatísticas apontam 1 caso de autismo para cada 150 nascimentos. A autora destaca, ainda, que os sintomas são diferentes nas meninas e há menos sinais tradicionalmente associados ao autismo clássico. Atualmente, diz-se que:

Houve aumento de quase $30 \%$ em relação aos dados anteriores, de 2008, em que apontava para 1 caso a cada 88 crianças. Quase 60\% para 2006, que era de 1 para 110. Mesmo o autismo podendo ser detectado a partir dos 2 anos de idade, a maioria das crianças foi diagnosticada após os 4 anos (PAIVA JUNIOR, 2014, s/p).

Conforme Orrú (2010, p. 7):

A abordagem histórico-cultural de Vigotsky está fundamentada na participação do outro na constituição do sujeito em sua relação com o mundo, por meio da ação mediadora. Ou seja, nenhum ser humano deve ser privado de se relacionar com outras pessoas, o ambiente onde as relações sociais são privilegiadas é o melhor e o mais adequado, independente desta pessoa ter ou não alguma deficiência.

Segundo a autora, o trabalho com autistas na perspectiva da abordagem histórico-cultural, deve contemplar uma criteriosa relação entre mediação pedagógica, cotidiano e formação de conceitos, possibilitando o encontro/confronto das experiências cotidianas no contexto em que elas ocorrem para a formação de conceitos, numa maior internalização consciente do que está sendo vivenciado e concebido. Esse trabalho necessita ser orientado na perspectiva do desenvolvimento da linguagem, uma vez que:

O aluno com autismo é um ser humano que deve ser respeitado em seus limites. Assim sendo, a linguagem adentra todas as áreas de seu desenvolvimento, orientando sua percepção sobre todas as coisas e o mundo no qual está inserido. É pela linguagem que o aluno com autismo, em seu processo de aprendizagem, sofrerá transformações em seu campo de atenção, aprendendo a diferenciar um determinado objeto de outros existentes, assim como a construir ferramentas internas para integrar estas informações (ORRÚ, 2010, p.13).

Nas palavras de Baptista e Bosa (2002, p. 19):

O atual estágio do conhecimento acerca dessa síndrome e da própria educação exige que essa temática seja inserida na discussão que integra a educação e as diferenças. Esse movimento não evita que sejam conhecidos e debatidos os aspectos peculiares aos sujeitos "autistas". Contudo, exige que conheçamos mais e melhor cada um dos sujeitos para os quais ousamos dizer: "O atendimento deve ser...". Se a necessidade de conhecer o sujeito é uma premissa, podemos compreender que esse conhecimento será integrado ao projeto e não será disparador de fórmulas estandardizadas de intervenção. 
Como propõe Vygotsky $(2005,2006,2007)$, a formação da identidade perpassa as relações sociais, estão presentes nas interações com o outro, na apropriação da cultura e no desenvolvimento da linguagem. O autismo é um assunto que exige estudos e aprofundamentos contínuos para se compreender as possibilidades de trabalho pedagógico na atenção à criança com autismo na educação infantil, visto que as interações sociais e os processos de subjetivação afetam a formação dos indivíduos de maneiras distintas, a partir das transformações estruturais do/no sujeito, mas, também, a partir da apropriação e interação com a cultura, as linguagens e o outro.

Os objetivos da pesquisa buscaram traçar perspectivas de trabalho pedagógico para auxiliar no processo de desenvolvimento de uma criança com autismo, atendida na educação infantil. Objetivou-se ${ }^{4}$ compreender as possibilidades do trabalho com autismo na educação infantil; construir práticas pedagógicas inclusivas, numa perspectiva de trabalho colaborativo5; e ampliar as possibilidades de desenvolvimento da criança com autismo.

\section{Metodologia}

Trata-se de um estudo de caso, do tipo etnográfico. O local da pesquisa foi um Centro Municipal de Educação Infantil (CMEI) da rede municipal de Vitória. Acompanhou-se uma criança diagnosticada com TEA. Sua identidade foi preservada, utilizando-se nome fictício. O presente artigo está pautado no reconhecimento da integralidade do sujeito e da necessidade de um trabalho pedagógico que amplie as possibilidades formativas da criança na educação infantil. O nosso objeto de estudo é o autismo e as possibilidades de desenvolvimento de Suely ${ }^{6}$ na relação com os pares e adultos do Centro Municipal de Educação Infantil (CMEI).

Conforme Ventura (2007), o estudo de caso como modalidade de pesquisa:

É entendido como uma metodologia ou como a escolha de um objeto de estudo definido pelo interesse em casos individuais. Visa à investigação de um caso específico, bem delimitado, contextualizado em tempo e lugar para que se possa realizar uma busca circunstanciada de informações.

Segundo Gil (1995), o estudo de caso não aceita um roteiro rígido para a sua delimitação, mas é possível definir quatro fases que mostram o seu delineamento: a) delimitação da unidade-caso; b) coleta de dados; c) seleção, análise e interpretação dos dados; d) elaboração do relatório. O período de intervenção/pesquisa correspondeu o período de 02 anos (fevereiro de 2014 a dezembro de 2016).

Os pais de Suely autorizaram o estudo mediante "TERMO DE CONSENTIMENTO LIVRE E ESCLARECIMENTO", bem como os profissionais que atuaram com a turma do Grupo IV ao longo de 2015. O sujeito da pesquisa é Suely, nascida em Vitória/ES, frequenta o turno vespertino do CMEI

4 Essa pesquisa se iniciou efetivamente em 2015, com perspectiva de encerramento no final de 2017.

5 [...] O ensino colaborativo ou coensino é um modelo de prestação de serviço de educação especial no qual um educador comum e um educador especial dividem a responsabilidade de planejar, instruir e avaliar a instrução de um grupo heterogêneo de estudantes. [...] o professor especializado que vai até a classe comum na qual o aluno está inserido colaborar com o professor do ensino regular (MENDES, ALMEIDA, TOYODA, 2011).

6 Nome fictício para preservar sua identidade. 
Constelação. De acordo com o laudo médico, datado de 06/06/2014, a criança foi diagnosticada com CID10 F84.0 (Autismo Infantil), caracterizando hiperatividade, agitação psicomotora e distúrbio da fala. Faz uso de medicamento: RESPIRINDONA 1 MG.

Por se tratar de uma pesquisa realizada na instituição de atuação docente dos pesquisadores, o trabalho foi concretizado em um horário de planejamento, fato que permitia o envolvimento de todos os profissionais que atuavam com Suely. Nesse caso, aproxima-se da perspectiva de uma pesquisa participante, na qual o professor pesquisa a própria prática. Adotou-se o registro sistemático em caderno de campo, com produção de vídeos e registro fotográfico.

Em 2015, o início do ano letivo para Suely foi um desafio. Considerando que algumas crianças com autismo podem apresentar sensibilidade às mudanças das atividades cotidianas, que a menor alteração afeta o comportamento e altera as atitudes do autista, a troca dos profissionais que atuavam com ela no ano anterior e o novo espaço de sala de aula foram potencializados pela perspectiva de mudança de professores ao logo do ano. Tendo em vista as férias prêmio da professora regente e a solicitação de aposentadoria, não foi possível estabelecer um planejamento sistematizado a longo prazo.

Outra professora assumiu o Grupo IV oficialmente por um período de 30 dias e aguardou a definição quanto à aposentadoria da professora titular. Nesse processo de revezamento, considerando a necessidade de rotinas para as crianças se apropriarem desse espaço institucional, construírem referências sociais, desenvolverem suas linguagens e conhecimentos, iniciamos os trabalhos nesse momento de transição de professoras. A proposta foi apresentada às professoras e prontamente aceita, uma vez que o quanto antes iniciasse o trabalho, as possibilidades de organização das práticas pedagógicas poderiam se estabelecer.

É importante destacar que as metodologias de trabalho dessas professoras seguiam abordagens distintas. Nesse sentido, Suely vivenciou perspectivas diferentes e organizações das mais variadas rotinas diárias e semanais. Essas mudanças nas rotinas e metodologias de trabalho docente exigiram articulações e intervenções pedagógicas contínuas. O primeiro semestre seguiu essa alternância de professoras e metodologias, fato que se encerrou no segundo semestre, com a chegada de uma professora regente concursada (lotação provisória) para suprir a aposentadoria da professora titular.

A escolha do horário de intervenção ocorreu de acordo com a organização dos horários da professora da Educação Especial e a disponibilidade do planejamento do professor de Educação Física (pesquisadores). Decidiu-se por ser na quinta feira, uma vez que as crianças jantariam às 16 horas e seria possível trabalhar 40 minutos com elas e a professora. Entretanto, por questões de ajuste de horário das cozinheiras, o jantar foi antecipado para as $15 \mathrm{~h} 45 \mathrm{~min}$. Dialogou-se para manter o horário anterior, contudo não houve flexibilidade por parte da pedagoga responsável em acompanhar essa turma.

Diante da impossibilidade de alterar o dia e as demais organizações já realizadas, optou-se em manter o trabalho às quintas feiras, porém, com um tempo de até 25 minutos de intervenção. Essa decisão levou em consideração a disponibilidade de todos os profissionais (Assistente de Educação Infantil, Estagiária e Professores) envolvidos com a turma, possibilitando a participação nas atividades planejadas. 
As intervenções foram articuladas ao projeto de sala, numa prática pedagógica compartilhada/dialogada. Concomitantemente, ocorreram as aulas de educação física às quartas feiras e o acompanhamento da professora de Educação Especial em sala de aula em dois momentos ao longo da semana, ampliando-se, assim, o tempo de observação e intervenção com Suely.

Já em 2016, a pesquisa ficou articulada ao projeto de sala da professora de Arte, numa prática pedagógica compartilhada no primeiro semestre; e no segundo semestre, numa integração ao projeto de sala da professora regente (realizado às terças feiras, no horário de 14:10 as 15:00 horas).

Nesse movimento de pesquisa, para além desse momento específico, a atenção e intervenções ocorreram também nas aulas de Educação Física duas vezes por semana (realizadas às segundas feiras, entre 14:10 e 15:00 horas); às terças-feiras, no horário de 16:10 as 17:00 horas,

A organização da instituição de Educação Infantil, em termos de Educação Especial, permitiu o atendimento na sala regular acompanhada pela professora da educação especial (pesquisadora) e, também, na sala de Atendimento Educacional Especializado (AEE), realizado no contra turno por outra profissional com formação específica. Suely passou a frequentar os serviços da APAE, ambos uma vez por semana. Adotou-se o registro sistemático para otimizar as trocas entre os diferentes profissionais, utilizando-se de um "caderno de registro" individualizado, entretanto, não foi possível articulação entre as duas instituições.

É importante destacar que está atrelado ao diagnóstico o direito ao acesso às políticas públicas para o Público Alvo da Educação Especial, no caso o TEA. Isso não garante que serão acessadas de imediato, todavia, trata-se de um pré-requisito para ser atendido pela equipe da educação especial. O diagnóstico precoce abre caminho para se buscar o acesso ao atendimento educacional especializado (AEE), ao acompanhamento psicológico e fonoaudiológico em estabelecimento externo ao ambiente da instituição de Educação Infantil (APAE), acesso a "tratamento médico" por profissional da saúde, a elaboração de um planejamento individualizado pela equipe da Educação Especial e a articulação do trabalho entre os diferentes professores atuantes na instituição infantil (trabalho colaborativo).

A intervenção precoce visa minimizar as dificuldades apresentadas pela criança, especialmente nas três áreas que o autismo se manifesta: comportamento, linguagem e interação social. Trata-se de oportunizar experiências que provoquem a criança a vencer essas barreiras a partir de diferentes estímulos. Buscou-se desenvolver as diferentes linguagens mediante estratégias pedagógicas que reconhecem a participação ativa do sujeito, articulada com as interações sociais, a partir das relações do sujeito com a cultura e a linguagem. Tais ações exigem a construção de espaços de reconhecimento e valorização das singularidades dos sujeitos e criteriosa relação entre mediação pedagógica, cotidiano e formação de conceitos, possibilitando o encontro/confronto das experiências cotidianas no contexto em que elas ocorrem para a formação de conceitos, numa maior internalização consciente do que está sendo vivenciado e concebido.

Outra estratégia adotada foi a divisão da turma que Suely acompanhava desde o berçário (Grupo II). Em 2015, após avaliação da equipe pedagógica e professores atuantes com o então Grupo IV, 
constatou-se que havia uma especificidade que interferia no processo de interação entre os pares. Outro fator ponderado pela equipe foi a necessidade de atender a uma demanda de algumas famílias que desejavam trocar os filhos de turno (matutino para o vespertino), uma vez que não era possível, tendo em vista existir apenas uma turma para essa faixa etária no vespertino.

Diante disso, a equipe decidiu organizar um Grupo V e um Grupo misto. As crianças foram distribuídas entre as turmas e a Suely ficou no grupo misto, mantendo-se 50\% da turma original. Os pais de Suely foram informados e ficaram preocupados, pois ela "poderia perder conteúdos" importantes para o seu processo de "alfabetização". Houve uma reunião pedagógica e foi informado aos pais sobre os motivos de mantê-la na turma mista, dentre eles, ser a única criança público alvo da educação especial (PAEE) na turma ${ }^{7}$; a possibilidade de interação com as crianças menores, facilitando sua comunicação verbal e, também, a importância de Suely se reconhecer como sujeito ativo na hora de interagir com os colegas, assumindo um certo protagonismo em algumas atividades de sala ou aula.

Também foi proposto o trabalho colaborativo como estratégia para ampliar as experiências formativas de Suely. Tal prática exigiu o compartilhamento de conteúdos, objetivos, ações pedagógicas e avaliação do processo. Houve necessidade de planejamento coletivo e, sempre que se efetivava uma aula ou vivência, os professores avaliavam se os objetivos para a turma foram alcançados e, especificamente, se Suely conseguiu participar efetivamente da experiência. Sendo ela o foco do estudo, todas as oportunidades de interações e estimulação das linguagens eram aproveitadas e pensadas coletivamente. Buscou-se refletir sobre os ganhos que ela expunha em termos de autonomia e expressão.

Ainda, como estratégia, adotou-se valorizar as potencialidades de Suely. Tendo em vista que ela demonstrava gostar de música e conseguir expressar-se corporalmente através da "dança", Suely possui um domínio significativo sobre o ritmo e conseguia acompanhar o andamento das músicas com desenvoltura. Também gostava de alguns temas específicos que tentávamos capturar e inserir nas aulas planejadas. Foi o caso dos dinossauros, do teatro de varas, do filme Frozen e seus personagens/músicas, instrumentos musicais, dentre outros. Valorizaram-se as interações e amizades que ela revezava ao longo do ano letivo. Ela sempre elegia algum colega para estar junto e buscava-se respeitar essas escolhas, pois a interação e a linguagem entre eles tornavam-se mais significativas. Essa capacidade de fazer escolhas sempre foi estimulada, mesmo quando seguiam no sentido contrário ao que estávamos propondo em aula.

Além disso, houve a constante tensão entre o reconhecimento das especificidades de Suely e as provocações pedagógicas, talvez uma concepção dialética ${ }^{8}$ do trabalho com o autismo. Dito de outra

\footnotetext{
7 No Grupo V havia outros casos e alguns acompanhamentos de criancas com dificuldades de aprendizagem e comportamento. A educação especial, no caso da educação infantil, atua também para auxiliar no processo de avaliação do desenvolvimento das crianças e encaminhamentos a outros profissionais quando necessário. Existia a necessidade de aguardar o retorno de algumas famílias para constatar se eram ou não PAEE.

$8 \mathrm{Na}$ concepção marxista, a dialética é uma ferramenta utilizada para compreender a história. A dialética marxista considera o movimento natural da história, e não admite sua maneira estática e definitiva. [...] a história quando é analisada como algo em movimento torna-se transitória, que por sua vez, pode ser transformada pelas ações humanas. [...] Por meio dessa relação dialética entre o ambiente, o organismo e os fenômenos físicos, os seres humanos, a cultura e a sociedade criam o mundo, ao mesmo tempo que são modelados por ele. [...] Por outro lado, para o materialismo dialético, o corpo e a mente são indissociáveis e os seres humanos podem modificar o mundo real, e não somente observa-lo (Fonte: https://www.todamateria.com.br/materialismodialetico/).
} 
forma, houve um trabalho sistemático que a todo o momento retirava Suely de sua zona de conforto: se o "olhar direto" não ocorria, criava-se estratégias para otimizar tal atitude; se a interação era seletiva, construíam-se atividades que envolvessem o maior número de crianças, às vezes com um grupo reduzido para ampliar as percepções de Suely; se não gostasse de uma textura ou tocar algo, planejava-se experiências ou vivências que ampliassem suas ações e minimizassem esses comportamentos/sensações. Num primeiro momento era possibilitada uma atitude de recusa, posteriormente havia o convite ou convencimento da necessidade dela participar da atividade; permitia-se a fuga, mas buscava-se o retorno tão logo fosse possível/percebido. Essa tensão indica uma estratégia na qual a autonomia da criança com autismo é construída no coletivo, no processo de mediação pedagógica, sem, contudo, abrir mão das singularidades do sujeito.

\section{Desenvolvimento: práticas e articulações pedagógicas}

Os trabalhos em sala de aula com Suely começaram em 09/04/2015. Conforme planejamento, iniciou-se com atividades de música. O violão foi utilizado para direcionar a intervenção e convidar as crianças para cantar músicas infantis e fazer os gestos. Partiu-se do que elas sabiam e dominavam, uma vez que já acontece esse momento da música ao longo de sua permanência na Educação Infantil (EI). A Dona Aranha, Pintinho amarelinho, O sapo, Jacaré, Patinho, Lagartixa, Ciranda cirandinha, Alface já nasceu foram algumas das músicas cantadas e coreografadas pelas crianças.

A condução do processo oportunizou a participação efetiva de Suely, ora acompanhando os colegas, ora decidindo junto com o grupo. A oralidade foi estimulada, sendo valorizado o saber das crianças e as memórias afetivas que tanto o momento de cantar, quanto as brincadeiras advindas dessas canções possibilitavam. Os gestos, as histórias e a fantasia também compunham esse trabalho, uma vez que o pensamento abstrato e o faz de conta são desejados no desenvolvimento social das crianças, independente de sua condição de desenvolvimento, pois, como propõe Vygotsky, o social se sobrepõe ao substrato natural.

As intervenções proporcionaram atividades com brincadeiras cantadas. Iniciou-se com a música "Jacaré está passeando na lagoa". As crianças acompanharam cantando em fazendo os gestos. Na sequência, trabalhou-se com a música "Boneca de lata" e as crianças fizeram os movimentos com intensidade e alegria. A brincadeira da "serpente", na qual as crianças são convidadas a compor o corpo da serpente passando por baixo das pernas dos colegas, foi iniciada e finalizou-se com a brincadeira da "Galinha do vizinho".

É importante pontuar que na relação com os colegas, Suely interagiu nas atividades propostas e conseguia participar efetivamente das brincadeiras. A fala era exigida e a atenção trabalhada em todos os momentos. Nesse sentido, as brincadeiras proporcionaram uma gama de experiências com o movimento, 
otimizavam-se as questões afetivas e o contato físico (toque) era exigido nas atividades, bem como permitiram que as crianças se organizassem para brincar. A mediação esteve presente na condução do processo e na intencionalidade planejada, ou seja, oportunizar o desenvolvimento do faz de conta e a autonomia dos sujeitos participantes do trabalho.

Também foi planejado algumas brincadeiras com cordas: passar níveis, equilíbrio, chicotinho queimado, o relógio, cobrinha e faz de conta utilizando as cordas (rio, jacaré, ponte, mar, tubarão...) e proposto um trabalho de esconde-esconde com o lençol. Essas atividades possuem como característica o brincar coletivo, sendo assim, Suely era convidada a interagir com os pares e, ao mesmo tempo, prestar atenção nos comandos direcionados em cada brincadeira. Havia o direcionamento intencional sobre a participação e compreensão das crianças, em especial Suely. Ela era provocada nominalmente, elogiada sempre que conseguia superar as dificuldades e efetivamente brincar com os colegas. A todo momento ela era convocada a se manifestar e, ao final, interpelada sobre sua experiência. Nesse movimento, buscava-se a autonomia, a iniciativa e o desenvolvimento da linguagem oral espontânea, intencional e consciente.

Outra experiência planejada foi um teatro de fantoches. A Suely estava dormindo no momento que chegamos à sala. Iniciamos a atividade após ela acordar e posicionar-se para acompanhar o teatro de fantoche. Selecionamos alguns personagens e montamos uma apresentação na sala de aula do GIV. Iniciamos com a "vovó e o vovô" (João e Maria). Houve interação com as crianças e a chamada dos personagens: "Galinha pintadinha", o "Mário" (um fantoche que jogava os cabelos - movimento de cabeça - sempre que falava) e "Galo Carijó". Convidamos as crianças para interagir com os personagens e cantar a música da Galinha Pintadinha. Seguindo com a apresentação, os vovozinhos entraram e chamaram mais dois personagens: o jacaré e o peixinho. Nesse momento, começamos a cantar a música do jacaré na lagoa e encenar com os fantoches. As crianças ajudaram a cantar e ficaram atentas aos movimentos, especialmente quando o jacaré morde o peixinho, sai de cena e retorna mastigando. Como houve um silêncio, decidimos inverter a história e encerramos a cena com o jacaré fugindo do peixinho.

Sem perder o foco da pesquisa, essa experiência permitiu que as crianças construíssem o pensamento abstrato e o faz de conta, importantes para o processo de desenvolvimento das funções superiores. A atenção exigida e a concentração permitiram que a consciência e a memória fossem trabalhadas nessa atividade. Com isso, a superação das limitações de Suely aconteciam processualmente. O nome das crianças era mencionado ao longo das histórias e isso permitia a consolidação da formação de suas identidades, em especial Suely. Havia, ainda, a interação com os fantoches reforçando a ideia de pensamento abstrato desejado nesse processo de mediação. Ao final, as crianças brincaram com os fantoches e interagiram com os adultos presentes e pares.

Retomamos o trabalho com as brincadeiras tradicionais. Levamos as crianças para o pátio, espaço do "campinho", colocamos os bambolês no chão e brincamos de "coelhinho sai da toca". Nessa atividade, utilizamos os bambolês e buscamos integrar a todos. Primeiro possibilitamos apenas a troca de lugares; em seguida, fomos tirando as crianças que ficavam fora da toca até sobrarem duas. A brincadeira "paraquedas". Essa atividade foi "mágica", a julgar pelos olhos vibrantes das crianças e adultos, pois 
houve interação e alegria de todos. Estar ora embaixo, ora fora (esconder e aparecer) permitiu um movimentar espontâneo. As bolinhas de plástico coloridas (utilizadas em piscinas de bola) foram acrescentadas à brincadeira e começamos a sacudir o tecido (TNT) tentando "levantar" as bolinhas. Em dado momento, entramos embaixo do tecido e "jogamos" as bolinhas para o alto.

É importante rememorar que, no caso de Suely, havia dificuldade nas três áreas que tipificam o autismo: interação social, linguagem e comportamento. Essas atividades, dentro do planejamento, oportunizavam a ruptura de seu isolamento social e exigia dela uma atitude autônoma e consciente. Nesse caso, entendemos que o processo de aprendizagem das habilidades sociais estava sendo otimizado com tais brincadeiras. Também é importante pontuar que as mudanças nas atividades e sua imprevisibilidade por parte das crianças auxiliaram Suely a superar várias barreiras advindas do quadro de autismo, pelo menos foi a nossa avaliação.

No dia 25/06/2015 fizemos um trabalho com os instrumentos musicais. As crianças sentaram no campo e distribuímos os instrumentos; pandeiros, chocalhos, tambores, agogô, tamborim e começamos a cantar e tocar músicas infantis. As crianças acompanharam os ritmos e, a cada duas músicas, trocavam os instrumentos com o colega. Suely aceitou bem essa proposta e interagiu com os colegas, efetuou a troca dos instrumentos sem reclamar e acompanhou tocando os instrumentos. É importante pontuar que nessa faixa etária as crianças apresentam dificuldade em executar dois comandos. Neste caso, elas faziam a opção de ora cantar, ora tocar e, além disso, ficam desejosas de tocar o instrumento do colega, ou seja, sua atenção fica dividida. Suely apresentou todas essas características.

O trabalho com ritmo e elementos musicais auxilia na organização espacial e sensorial da criança. Perceber que Suely se manteve na roda, ficou atenta ao andamento das músicas, interagiu com os pares e aceitou a mediação dos professores foi um indicativo de que o processo de aprendizagem estava acontecendo, conscientes da expectativa que tínhamos sobre os comportamentos desejados e esperados por nós adultos. Destarte, o tempo de desenvolvimento é único para cada sujeito e as apropriações podem ocorrer em momentos diferenciados, não necessariamente no instante da atividade. Nesse sentido, trabalhava-se com o interesse das crianças, em especial Suely que demonstrava gostar de cantar e tocar instrumentos de percussão (tambor) com desenvoltura.

Foram nove intervenções durante o primeiro semestre, tendo em vista a dinâmica do CMEI, com feriados, assembleias ou reuniões, ausência dos participantes da pesquisa e dificuldades com o ensaio para a festa cultural. Nesse período de intervenções, Suely apresentou um avanço significativo no seu desenvolvimento da linguagem oral, conseguia articular várias palavras que auxiliavam na comunicação direta, a partir de frases curtas ou palavras-frase, tais como: "obrigada", "licença”, "não quero", "me dá", "não", "sim". Também ocorreram ensaios de diálogos com os colegas e com o(a) professor(a), mesmo não se compreendendo sua fala. Demonstrava ser carinhosa, aceitava ser abraçada e gostava de interagir com os professores. Essa apropriação da linguagem foi significativa para o seu processo de construção da identidade e interação com o grupo. Isso refletiu diretamente no seu comportamento, pois conseguia 
brincar com alguns colegas, buscava estar junto ao grupo e tentava participar de atividades espontâneas em algumas ocasiões.

Conforme Padilha (2004):

O progresso intelectual do ser humano ocorre através do desenvolvimento da função simbólica, onde a linguagem e a emoção constituem papel fundamental. Para Vygostsky, conhecer o homem, estudar sua vida psíquica, tratava-se de estudar suas relações concretas de vida, através do materialismo dialético histórico, onde as ações humanas são integradas em ações significativas. Para o mesmo, isso ocorre através de instrumentos psicológicos: a linguagem, o cálculo, a álgebra, os mapas, desenhos, sistema de numeração, todos os signos estabelecidos por convenção, ou seja, através do construtivismo. A palavra é o signo por excelência, no entanto uma palavra sem significado é um som vazio.

Outra atividade trabalhada em 2015 foi uma brincadeira historiada (Os três porquinhos) no pátio. Construímos três espaços com tecidos para esconder os "porquinhos" e a professora da educação especial foi o "Lobo Mau". À medida que contávamos a história, as crianças corriam para se esconder e interagiam com os personagens. A fala e os estímulos à Suely foram prontamente acatados. Ela compreendeu a dinâmica da brincadeira e interagiu com os colegas e adultos. Ao final, as crianças caíram sobre a professora e Suely foi ao socorro, tentando "salvar" a professora. Não demonstrou medo, pelo contrário, envolveu-se na fantasia e demonstrou compreender o que estava ocorrendo.

Conforme Martins (2013, p. 215), “a evolução do conteúdo do pensamento é um processo de desenvolvimento cultural, histórica e socialmente condicionado que supera, por incorporação, as bases elementares e estruturais do psiquismo - inclusive as orgânicas". Esse processo reside na formação de conceitos, que sintetiza em suas diferentes formas o movimento evolutivo do pensamento, ou seja, não há desenvolvimento do pensamento sem internalização dos signos.

No caso da atividade relatada, a imaginação foi o ponto central potencializado com as crianças. Conforme Martins (2013, p. 226) “[...] a imaginação possui suas singularidades e um curso de desenvolvimento fundamentalmente alinhado ao desenvolvimento da linguagem, do pensamento e dos sentimentos".

No dia 12/11/2015 desenvolvemos um "Circuito Sensorial”. As dinâmicas atreladas a outras atividades compreendidas na instituição de Educação Infantil, colaboraram para os avanços apontados no desenvolvimento da criança. Nessa dinâmica em particular, Suely mostrou a real importância na interação com o outro, pois, tocou em diversas texturas que jamais colocaria as mãos no ano anterior, como: palha de aço fina, lixa, folha seca, areia, algodão e bolinhas gelatinosas. Esses materiais fizeram parte dos atendimentos no AEE (contra turno) no ano de 2014 e Suely se recusava plenamente em tocar. Ela surpreendeu na forma como entendeu, colaborou e participou juntamente com seus colegas de turma. Fez-se presente nos quatro ambientes do circuito: começamos no refeitório apresentando o aroma e sabor de frutas que não constavam no cardápio do CMEI. O abacaxi foi a sensação do momento, seguido pelo morango, laranja e a uva. Suas mãos deslizaram pela casca do abacaxi. 
Já na sala de informática, que foi transformada numa discoteca na qual a música vinha do chão através de um tapete de "plástico bolha", ela se encantou com as luzes do laser, strobol. A fumaça do gelo seco a deixou agitada e com medo, todavia, as bolhas no chão a encheram de prazer. $\mathrm{Na}$ estação do "fundo do mar", as imagens coladas no teto da sala de movimento refletidas na luz negra, representavam exatamente a sensação de bem estar. Suely, ficou encantada, contudo, rejeitou o cheiro no ar que foi borrifado com aromas baunilha e laranja. Essa trilha sensorial se encerrou no pátio, com várias subestações: pó de serra (fino e grosso), cordas, isopor, folhas secas, areia, tecido, lixas, palha de aço, espuma, algodão e bolinhas gelatinosas na água.

Faz necessário pontuar que as funções superiores e o desenvolvimento do psiquismo estão em estreita relação com os processos funcionais, em especial as sensações, a percepção, a atenção. Conforme Martins (2013, p. 122), o processo funcional sensação corresponde à "porta de entrada" do mundo na consciência. A autora propõe que "a sensação reflete as qualidades isoladas dos objetos e fenômenos do mundo material as quais atuam diretamente sobre os órgãos dos sentidos [...]”. Nesse sentido, a superação por parte de Suely ao tocar e vivenciar as diferentes experiências sensoriais colaboraram para ampliar suas possibilidades de desenvolvimento.

Assim, verifica-se que a percepção do ser humano é historicamente condicionada, não sendo uma mera complexificação do ato sensorial. [...] Toda percepção de um objeto pressupõe sua integração a um sistema de representações ou conceitos, condicionandose a ele, de tal forma que a percepção do mundo, de seus objetos e fenômenos se realiza pela perspectiva da consciência social (MARTINS, 2013, p. 140).

Nesse processo de desenvolvimento e permanência no CMEI, Suely demonstrou interesse, bem como o envolvimento com as propostas desenvolvidas e conseguimos avanços significativos na sua forma de se relacionar com os colegas e adultos que convivem com ela. No entanto, ainda apresentava alguns momentos de isolamento onde observava com bastante atenção tudo o que acontecia ao seu redor. Contudo, gostava de ser o centro das atenções. Criava brincadeiras, buscava parcerias, compartilhava brinquedos e brincadeiras.

O que chama a atenção no seu desenvolvimento são os aspectos da linguagem e a troca de olhar. Suely, como uma característica típica do autista, possuía uma tendência em desviar o olhar sempre que estava se comunicando, não conseguia resistir à troca de olhares diretos (olho no olho). A avaliação que fazemos é que ela já consegue, e até busca, esse olhar direto, demonstrando uma transformação efetiva nesse comportamento, auxiliando-a no processo de comunicação e interação social.

A agressividade, presente desde o início nas interações de Suely, foi algo que ela conseguiu a aprender e controlar. É possível avaliar que à medida que ela se apropria da linguagem oral (fala) e consegue se expressar, passa a ser compreendida pelos colegas e isso lhe dá segurança. Contudo, quando ela está concentrada em uma atividade isolada, a exemplo da "seriação" das bolas em uma aula de educação física, "vira uma leoa" e briga com qualquer um que interfira na atividade, incluindo o professor. Os colegas, também, já conseguem compreender seu comportamento e alertam aos demais quando estão irritando Suely. Essa interação entre pares é significativa para que ela se sinta acolhida no grupo, trata-se 
da perspectiva do "espelho": aprendemos com o outro, nossos comportamentos são refletidos no outro e nos apropriamos das regras sociais.

O trabalho realizado ao longo de 2016 continuou a ampliar as possibilidades de Suely diante do Transtorno do Espectro do Autismo (TEA), uma vez que são apontadas diferentes estereotipias apresentadas pelo sujeito com autismo, tais como: deficiência persistente e clinicamente significativa da comunicação e da interação social; padrões restritivos e repetitivos de comportamentos, interesses e atividades, manifestados por comportamentos motores ou verbais estereotipados ou por comportamentos sensoriais incomuns; ausência de reciprocidade social; excessiva aderência a rotinas e padrões de comportamento ritualizados; interesses restritos e fixos; profundo isolamento para o contato com as pessoas, falta de empatia, criatividade e incapacidade de fazer amigos; desejo obsessivo de preservar a identidade, expressado pelo desejo de viver em um mundo estático, onde as mudanças não são aceitas; estreita relação com os objetos, e outros.

Contudo, há que se considerar que o autismo se manifesta de forma ímpar e particular, ou seja, somos seres únicos e isso se aplica à pessoa com autismo. Desta forma, algumas estereotipias ou comportamentos nem sempre serão replicados por outro caso, bem como as perspectivas de desenvolvimento estão condicionadas às experiências sociais e históricas vividas pelos sujeitos.

Nesse sentido, diante das possibilidades observadas ao longo da permanência de Suely no CMEI e suas potencialidades, buscou-se atividades que minimizassem algumas dessas estereotipias do TEA, oferecendo à Suely experiências didático-pedagógicas que estimulassem seu desenvolvimento, especialmente a linguagem oral, tendo em vista que tal habilidade interfere diretamente na capacidade de comunicação e expressão de seu pensamento (Vygotsky, 2005), na manifestação de suas vontades/desejos/necessidades e memória. Buscou-se, ainda, oferecer diferentes estímulos, a partir da participação ativa do sujeito, articulada com as interações sociais, nas relações do sujeito com a cultura e o conhecimento.

As possibilidades de trabalho na educação infantil estão respaldadas nas diretrizes curriculares nacionais (Brasil, 2010). Os eixos "interações e brincadeiras" nortearam o fazer pedagógico nas experiências e vivências oferecidas às crianças, tendo o caráter lúdico como componente das práticas desenvolvidas ao longo do ano letivo. $\mathrm{O}$ acesso à cultura corporal e as experiências/vivências desenvolvidas na educação infantil potencializam as capacidades desses sujeitos e contribui para que alcançasse uma melhor qualidade de vida, com progressão da autonomia e independência das crianças com deficiência. Para além, permite o acesso às diferentes linguagens e, também, o desenvolvimento das suas capacidades cognitivas e sociais. As crianças expressam sentimentos, emoções e pensamentos, ampliando as possibilidades do uso significativo de gestos e posturas corporais quando são oportunizadas experiências de/com o movimento, compreendido como uma linguagem que permite às crianças produzirem sentidos e significados, bem como a produção de conceitos integrados às outras linguagens.

Os objetivos traçados para as áreas de Educação Física e Arte contemplaram oportunizar o acesso ao conhecimento e experiências de/com o movimento; explorar dos conteúdos de Artes: ponto, linha e 
formas a partir de brincadeiras e jogos; desenvolver a criatividade e expressão corporal; ampliar as diferentes linguagens; possibilitar o acesso aos trabalhos de Kandinsky; oportunizar atividades de desafio e exploração da cultura corporal; desenvolver a autoimagem, autoestima e autonomia a partir de experiências de/com o movimento; oferecer o acesso a conteúdos de Arte e Educação Física a partir de uma abordagem interdisciplinar; e dialogar com o tema "diversidade", abordado no projeto institucional. Entendemos que tais objetivos foram trabalhados e alcançados ao longo de 2016.

Os recursos materiais utilizados foram os mais diversificados, tais como: cordas, slackline, mini trampolim, pneus usados, instrumentos musicais, amarelinha, tecidos, "redes de dormir", madeira paraju (trave), arcos para bola de sabão, brinquedos, peteca, piscina, argola e trapézio, trepa trepa (grade), bola de Pilates, blocos de espuma, bolas de diversos tamanhos e cores, bambolê, balanço, gangorra, escorregador, colchões, aparelho de som, bola de soprar e outros. Esses recursos pertencem ao patrimônio da instituição e foram adquiridos ao longo da permanência na instituição. Vale destacar que a "crise financeira", anunciada pela mídia e administração municipal, impediu o avanço na aquisição de novos materiais, consequentemente, algumas práticas planejadas não foram realizadas, tais como: atividades de musicalização com outros instrumentos (teclado, bateria, violões infantis, tambores, etc.) atividades aquáticas, cinema, teatro, lutas, capoeira, atividades artísticas e expressivas.

Nas intervenções, tanto nas aulas regulares e no projeto sobre o autismo na educação infantil, Suely demonstrou interesse e desejo em estar no pátio, em companhia dos colegas e adultos (professor e estagiária). As atividades possibilitaram o desenvolvimento das crianças em suas diferentes dimensões. Contemplou-se as brincadeiras tradicionais da infância, alguns esportes com bola e de aventura, movimentos ginásticos, música e dança, desafios, atividades expressivas, brincadeiras espontâneas com brinquedos, construção de brincadeiras com regras, exploração do espaço externo à sala (pátio) com atividades dirigidas e livres, bem como intervenções integradas com a área de Artes. É importante pontuar que o trabalho na educação infantil tem por princípio a integralidade do sujeito, bem como a perspectiva de um currículo integrado, no qual os conteúdos e objetivos estão inter-relacionados, são interdependentes e exigem uma avaliação contínua do processo de desenvolvimento dos sujeitos em suas diferentes dimensões: sociais, afetivas, cognitivas, motoras, estéticas e outras.

Os conteúdos das aulas de Educação Física foram organizados semanalmente, buscaram ampliar as possibilidades de desenvolvimento e formação humana. Consistiu em um trabalho intencional e dirigido nos diferentes tempos e espaços da instituição de educação infantil, com apoio pedagógico das Assistentes de Educação Infantil e Estagiárias, fundamentais para qualificar o trabalho docente e a ampliação das possibilidades de exploração dos materiais/atividades por parte das crianças.

A sala de movimento, um espaço preparado com tatame de $2 \mathrm{~cm}$ de espessura, espelho e barras para apoio, foi explorado ao longo do semestre. Foram oportunizados momentos de dança, relaxamento e atividades com os blocos de espuma. Nesse processo, as crianças interagiram e construíram possibilidades expressivas, com criatividade e espontaneidade. Eram estimuladas a vivenciar movimentos de subida, rolamento, descida e queda. Também foram possibilitadas experiências de movimento livre e brincadeiras 
espontâneas, a partir da exploração dos blocos/rolos/estruturas de espuma, bolas variadas, bola de Pilates, jogos de encaixe, pneus e brinquedos variados.

O pátio, espaço destinado e desejado pelas crianças, possui três divisões: área com brinquedos grandes e casinhas; área coberta com palco e som; e área aberta com grama sintética - campo. Ao longo do semestre foram oferecidas às crianças experiências de movimento dirigidas e espontâneas, possibilitando a ampliação das suas capacidades, linguagens, o desenvolvimento da autonomia e criatividade pelas crianças. São oportunizadas atividades espontâneas ao longo do semestre, visto que a criança necessita se expressar de diferentes formas, construir sua autonomia e interagir com os pares de maneira cordial e responsável. Sendo assim, são utilizadas músicas variadas e de conhecimento das crianças para que se expressem livremente, jogos, brinquedos e instalações.

Outra atividade desenvolvida com as crianças foi a escalada. Aproveitando a "parede" montada no pátio e o material disponível para segurança, oportunizamos o desafio às crianças e interagimos na superação dos medos e a experiência corporal de queda, subida na vertical, sustentação e descida de ponta-cabeça. O revezamento, a espera, a torcida pelo colega, a disputa entre eles foram movimentos percebidos e mediados ao longo do processo de intervenção.

Foram oportunizadas atividades com brincadeiras tradicionais, tais com o Balanço, Amarelinha, Bola de sabão, Túnel psicomotor, e Atividades variadas com pneus. As crianças tiveram a possibilidade de vivenciar e explorar essas brincadeiras ao longo do semestre. Foram vários momentos de atividades em grupo, com possibilidade de mediação e construção de valores sociais, a exemplo da utilização de palavras de cortesia (desculpa, obrigado e por favor) e formação de valores sociais. Ao longo dessas práticas as crianças exerceram a iniciativa, autonomia e criatividade, compartilhando experiências e saberes consolidados nesse tempo de permanência no CMEI. Ocorreram, também, momentos de interação entre turmas, possibilitando a convivência no mesmo espaço e a colaboração na cultura de pares.

A caixa de brinquedos variados (carrinho e pistas hotwheels, bonecos de super-heróis, Barbie, Ken, carros, brinquedos do Mcdonald's, bonecas, celulares velhos e outros) foi utilizada ao longo do semestre. Além do acesso a esses artefatos culturais, os momentos de aula possibilitaram o desenvolvimento da criatividade, a exploração do faz de contas, o desenvolvimento da linguagem oral, a interação social e a construção de valores. As crianças aprenderam a respeitar o espaço do colega, a dividir os brinquedos, a cuidar para não quebrar e organizar os objetos ao término da aula. Também foi possível observar que o tempo de concentração e a atenção desprendida nas atividades permitiram ampliar as capacidades das crianças.

Outros conteúdos foram trabalhados ao longo do semestre: utilização de Bola de Pilates e exploração da Trave de equilíbrio, como elementos da Ginástica; Esportes com bola, tais como Futebol e Basquete; e Exploração de bolas variadas, bem como o trabalho com tecido e música, utilizando-se de instrumentos (Violão e pandeiro). A abordagem seguiu uma perspectiva lúdica e fomentou a interação entre crianças e adultos. Foi possível trabalhar várias músicas infantis, brincadeiras cantadas e experiências corporais variadas, uma vez que os tecidos possibilitaram o movimentar das crianças em diferentes 
ângulos, planos e estruturas. Tais práticas corporais fazem parte da cultura corporal e foram oferecidas ao longo do semestre.

O "Trepa-trepa" foi outra atividade desenvolvida no pátio do CMEI. Houve a possibilidade das crianças explorarem movimentos de sustentação, cambalhota, pendurar-se com uma mão, soltar as mãos e manter-se sustentado pelos pés, desafio de subir e manter-se equilibrado sobre a estrutura, saltar sobre o colchão, construir estratégias para subir na estrutura utilizando-se de suporte (pneus), trabalho em equipe. Com relação ao comportamento e atitudes, as crianças compreenderam que havia necessidade de respeitar o espaço do outro, evitar movimentos que colocassem em risco o "equilibrio" dos colegas, ajudaram uns aos outros nos momentos de dificuldades e construíram diferentes possibilidades de explorar a instalação do trepa-trepa. Algumas crianças demonstraram medo e preferiram ficar à parte e observar as atividades dos colegas. A autonomia na escolha e a iniciativa também formam estimuladas ao longo das atividades, bem como o processo de interação contínua entre crianças e adultos que acompanharam as atividades, num processo de mediação.

Também foi oferecida a prática do Slackline, esporte que envolve andar e se equilibrar em cima de uma fita apropriada. Possibilitou o desenvolvimento da autoestima uma vez que as crianças exploraram o espaço e foram desafiadas a vencerem a travessia, inicialmente com ajuda do professor e colegas, até tentativas de exploração individual. Nesse processo, as crianças trabalharam a autonomia e o trabalho colaborativo. Além de trabalhar a concentração, melhora o equilibrio, controle da respiração e fortalecimento muscular. As crianças, também, exploraram o material com criatividade, executando movimentos de saltos, quedas e manobras variadas, uma vez que os colchões possibilitaram tais movimentos, sempre mediados pelo professor.

No projeto de pesquisa, nas aulas de Artes a partir do trabalho colaborativo entre os professores de Educação Física, Artes e Educação Especial foram vivenciadas várias experiências significativas para o desenvolvimento de Suely. O projeto "Brincando com Kandisky" orientou as práticas com a turma e otimizou diferentes momentos de ensino e aprendizagem das crianças. Algumas práticas pedagógicas desenvolvidas foram: Desenho livre sobre papel; Pintura mágica com giz branco e tinta anilina; Confeccionar fantoche - confecção de cenário - O Cavaleiro Azul; Experiência teatral com os personagens da primeira fase das obras de Kandinsky; Experiência com música clássica e pintura livre com tinta; perceber a vibração a partir de instrumentos musicais e pintar com a música; Experiência lúdica utilizando o movimento das linhas; dança-desenho, com exploração de música em sala e no pátio. Esse trabalho foi registrado sistematicamente em vídeos e fotos.

\section{Avaliação do processo de desenvolvimento}

Num contexto geral, podemos dizer que Suely vem se superando a cada dia. Ela "interage" muito bem com colegas, professores e demais profissionais da instituição de Educação Infantil. Agora que começou a manter diálogos, quer falar o tempo todo, relatar fatos vividos, vistos, ouvidos. Vem 
surpreendendo cada vez mais. É uma criança linda, alegre e cativante. Suely demonstrou avanços significativos na fala e interação social. As tipologias típicas de pessoas com autismo (isolamento, resistência a mudanças na rotina, ausência de reciprocidade social, desejo obsessivo de preservar a identidade - desejo de viver em um mundo estático - , estreita relação com os objetos e outros) já não são observadas facilmente, manifestando-se esporadicamente.

Educar é lançar um 'novo' olhar sobre o aluno, escolher atravessar a fronteira de um país rico em significados. Perder-se por entre os labirintos do conhecimento. A estrada trilhada pelo professor é apenas uma das possibilidades, dentro de uma região onde os caminhos e sentidos proliferam (VASQUES, 2008, p. 168).

Suely apresentou grande avanço na linguagem oral. Passou a articular pequenas frases e houve aumento de seu vocabulário, com isso se tornou mais independente e adquiriu maior autonomia, passou de palavras soltas para construção de frases. É capaz de manter pequenos diálogos e vem se desenvolvendo significativamente. Consegue articular várias palavras e organiza o pensamento de forma a ser compreendida pelos colegas e adultos. Ela tem ampliado seu vocabulário, apropria-se de expressões cotidianas e constrói/elabora possibilidades para se expressar com autonomia. Consegue olhar nos olhos dos colegas e adultos, busca essa interação visual em vários momentos de sua permanência no CMEI.

Em um dos dias em que caminhava próximo à janela, a professora da Educação Especial a chamou para se juntar aos colegas na roda de conversa. Suely ficou nervosa, parou, olhou e disse: - Me deixa tia "Cala", com o braço esticado em minha direção, estou pensando! Vai cuidar das suas coisas. A professora expressou que sentiu uma imensa felicidade por ver que agora Suely demonstra seus sentimentos, vontades e opiniões podendo se expressar de forma tão clara (sic).

Vygotsky (2001) afirma existir, no desenvolvimento da linguagem infantil, um período prélinguístico do pensamento e um período pré-intelectual da fala. Destaca que uma palavra desprovida de significado não é palavra, e sim, um som vazio. É importante observar que o desenvolvimento linguístico infantil, enfrenta um caminho com diferentes campos dentro da fonética e da semântica. Quando a criança inicia sua fala exterior, ela começa por uma palavra, e vai evoluindo no sentido de articular duas ou três palavras entre si, até o momento em que sozinha consegue elaborar frases complexas. Desse modo, se o progresso da fala em direção ao todo, caracterizado pela formação de uma frase, ajuda o pensamento da criança a progredir de um todo homogêneo para partes bem definidas, é notável a evolução já alcançada por Suely.

Suely ainda apresenta dificuldades em se colocar no lugar do outro, de compreender ou diferenciar ações que são intencionais ou acidentais que a afetam fisicamente ou interferem no seu espaço/tempo de ação. Ainda tem resistência a mudanças na rotina, fica irritada e corre para longe quando não é compreendida. Já expressa afetividade com os adultos, aceita e retribui gestos de carinho, mesmo quando se encontra em outro espaço/tempo da instituição, contudo ainda apresenta certa dificuldade na interação social, permanece tendo rompantes de agressividade "quando contrariada". Demonstra dificuldade quando tem que compartilhar a atenção dos adultos, podendo apresentar comportamento agressivo para com os colegas. Esse processo pode ser observado no relato da professora da Educação 
Especial: - Recordo-me quando era menor, em 2014 quando a conheci, tinha apenas três anos. Vinha para o AEE (Atendimento Educacional Especializado) no contraturno, queria sempre se sentar, organizar e seriar objetos. Quando eu tentava fažer intervenção para realizar outra atividade, ficava nervosa porque não falava, então, jogava tudo o que via pela frente em mim e às vežes me batia. Umas das soluçôes que encontrava para acalmá-la era levá-la para o pátio, onde a mesma se misturava às crianças do turno na aula de Educação Física onde se divertia e controlava a ansiedade.

O início do segundo semestre foi um pouco agitado para Suely, houve um período em que precisou ficar na casa dos avós devido sua casa estar em reforma, assim sua rotina foi quebrada. Desse modo, observou-se que a mesma passou a chegar mais agitada no CMEI, com menos paciência para os movimentos que aconteciam, passou a ser mais agressiva com os colegas e profissionais. Antonio ${ }^{9}$ ainda era seu melhor amigo, mas, passou a dizer que era seu amor e ficava muito nervosa caso outra criança chegasse perto dele. Para tentar contornar essa situação, realizou-se intervenção com a história do "Minhoco apaixonado". A partir daí, todos os dias havia uma conversa e orientação diferente sobre a questão do namoro tanto do CMEI, quanto da família. Com o passar do tempo, desapegou-se do Antônio e passou a interagir com os outros colegas de sala.

A professora regente que se encontrava em sua sala, precisou entrar de licença médica, então, uma nova professora assumiu sua turma. Ressalta que Suely não apresenta resistência em se relacionar com pessoas novas, mas, houve uma quebra de rotina novamente. Dessa vez, todas as vezes que era necessário chamar a sua atenção por algo que havia feito, ou, se ficasse nervosa em diferentes situações, mordia seu colega, sempre o mesmo menino. Foi feita uma intervenção com a família e todas as vezes que a ela se comportava dessa forma, a família era chamada na instituição no momento do ocorrido. O resultado foi fascinante, porque os pais tomaram a decisão de aplicar "castigos" em casa (deixar de assistir filmes ou desenhos, não ir a determinados lugares, deixar de utilizar tablet, etc.), dessa maneira, Suely conseguiu compreender que o que fazia era errado. Nesse caso, a equipe ficou bastante satisfeita, já que a família conseguiu compreender que precisavam se posicionar. O CMEI vinha mantendo diálogos nesse sentido ao longo dos anos, entretanto, percebia-se que o pensamento da família se encontrava focado na deficiência e não, a criança em si.

Ao longo do ano letivo, Suely demonstrou interesse nas atividades do CMEI, chegava alegre e busca interagir com todos, fruto desse processo de interação, mediação e atividades pedagógicas que eram trabalhadas com as crianças na instituição. Todos os dias, passa um período andando de um lado a outro na beira da janela da sala sem querer ser incomodada, provavelmente, estava organizando seu pensamento $^{10}$. Esse tempo é muito importante para ela e seus colegas o respeitavam plenamente. Esse comportamento pode ser visto no relato a seguir: Certo dia, disse à professora que queria um cavalo. A professora

\section{Nome fictício.}

10 Muitas vezes, as crianças enfrentam situações em que devem escolher entre opções conflitantes [...]. Ao tomar tais decisões, elas precisam conciliar o conflito entre escolhas disponíveis que se opõem no contexto de um conjunto específico de expectativas e regras, bem como controlar os impulsos para a gratificação imediata em benefício de uma escolha que é menos imediata e automática. Esse tipo de controle comportamental e cognitivo está relacionado ao conceito das funções executivas. As funções executivas são processos multidimensionais de controle cognitivo que se caracterizam por serem voluntários e exigir um alto esforço. Eles incluem a capacidade de avaliar, organizar e alcançar metas, bem como a capacidade de adaptar o comportamento com flexibilidade ao ser confrontado com novos problemas e situações (fonte: http://www.enciclopedia-crianca.com/funcoesexecutivas/segundo-especialistas/funcao-executiva-e-desenvolvimento-emocional). 
The disse que um cavalo era um animal muito grande e que não caberia em sua casa, dessa forma, Suely foi caminhar próximo à janela, quando retornou disse que havia pensado e já tinha uma solução, o pai teria que comprar uma casa maior. A professora da Educação Especial, diante dessa constatação, relata: - Quantas vezes, ao longo desses quatro anos, fiquei me perguntando o que ela pensava quando estava nervosa? De que forma organizava seus pensamentos e ações? Por que agia dessa forma? Finalmente obtive a resposta para as minhas indagaçoes.

Com relação ao projeto de intervenção, no segundo semestre optou-se por explorar instrumentos musicais no intuito de que Suely se interessasse e viesse a cantar. As intervenções ocorreram uma vez por semana, através do trabalho colaborativo entre professores de Educação Especial, Educação Física e regente. Foram apresentados e utilizados por Suely e sua turma os seguintes instrumentos: baquetas, pandeiros, chocalhos, violão, cavaquinho e tambor. Nas aulas de música, ela apresentou interesse e envolveu-se na proposta. A cada semana trabalhava-se com um grupo de 9 a 10 crianças, mantendo-se Suely e revezando os colegas de turma. Constatou-se que Suely interagia maravilhosamente bem com a música, seu corpo se movimenta no ritmo de cada som, o dançar vinha muito à frente do cantar. Enquanto os colegas tocavam e cantavam, Suely preferia tocar e dançar. Foram poucos os momentos em que resolveu acompanhar a música cantando.

Nessas aulas, às vezes ficava desinteressada e passava a observar de longe pelo espelho, uma maneira particular de aprender que Suely possui. As noções rítmicas e a percepção espacial são adequadas à faixa etária e já apresenta qualidade no acompanhamento das músicas. Sua atenção e concentração têm melhorado significativamente, contudo ainda carecem de trabalho mais sistematizado. Diante desse quadro, as músicas foram enviadas á família e solicitado que mediassem esse processo de aprendizagem em casa, com vistas a potencializar o seu envolvimento, fato confirmado durante a apresentação de encerramento. Foram quatro músicas trabalhadas, sendo três delas com "voz e violão" e uma com instrumentos musicais (chocalhos, caxixi e maracas). Suely, junto à turma, cantou, tocou, dançou e se divertiu diante das famílias e colegas de CMEI.

Sua a autonomia é cada vez mais visível e exercita a suas capacidades de fazer escolhas nas ações cotidianas, tais como: dizer sim ou não para algumas atividades, escolher uma música, decidir sobre o brincar e com quem interagir, optar por uma cor no momento de pintar, participar da atividade dirigida e outras. Suely consegue manifestar alguns de seus desejos e preferências.

Demonstrava estar encantada com o mundo dos dinossauros, imitava os animais e brincava com os colegas nos momentos espontâneos. Suely continua tendo seu próprio tempo para realizar as atividades propostas em sala, os momentos coletivos ainda são os seus favoritos. Contudo, percebe-se que a mesma tira proveito das situações, já percebeu que não é muito cobrada quanto às atividades a serem desenvolvidas. Conforme a professora da educação especial, a impressão que se tem, é a de que: "Os outros fazem, mas eu não vou fazer, porque os adultos não irão cobrar isso de mim".

No processo de alfabetização e apropriação da leitura e da escrita, Suely faz uso da ficha para escreve seu nome, reconhece várias letras do alfabeto, conhece alguns numerais, mas, ainda não quantifica. Nas atividades em sala, já identifica a letra do seu nome, mas resiste em "escrever" (na hora de identificar 
os trabalhos individuais). Interessa-se em pintar, e o faz com qualidade. Consegue compreender/executar vários comandos diretos ao longo das atividades integradas com Arte. Isso demonstra sua inserção e atenção (ainda em processo de consolidação) nas atividades desenvolvidas, seu envolvimento e desejo de estar participando com o grupo. A professora de Arte consegue boa mobilização e interação com Suely, que permanece em sala sem resistência. Alias, foram poucas as ocasiões que percebemos esse comportamento.

$\mathrm{Na}$ alimentação, devido às restrições da dieta a que está submetida ${ }^{11}$, demonstra resistência em aceitar uma comida diferenciada. Fica emburrada, nega-se a comer e, às vezes, faz pirraça. Contudo, seu comportamento demonstra a capacidade de escolha e preferências que já desenvolveu. Senta-se com o grupo e espera, junto com os colegas, até a hora de seguir para outro ambiente ou retornar à sala de aula.

Nas aulas de Educação Física, Suely consegue brincar com intensidade e explorar as possibilidades de movimentos oferecidas. Interage com os colegas com desenvoltura, expressa sua opinião com vigor e busca ser compreendida pelos colegas. Nos momentos de conflitos, já consegue conversar e buscar resolver por conta própria, recorrendo a um adulto quando ocorre agressão física consigo ou com um colega. Está atenta às atividades e chega a corrigir os colegas quando percebe que estão dispersos. Em algumas aulas, Suely não aceitava a proposta e ficava brincando à parte com algum colega, que também não deseja participar (Autonomia na escolha, concedida pelo professor).

A escola, instituição social configurada como espaço por excelência da educação e da mediação social sujeito-sociedade, detém a função social irrevogável e fundamental de oferecer condições potenciais para que os conhecimentos produzidos historicamente pela humanidade sejam devidamente democratizados, apropriados e objetivados pelos alunos, independentemente de suas condições físicas, intelectuais, socioeconômicas e culturais (CAIADO; Laplane, 2009; FONSECA, 2011; TRAVERSINI et al., 2012 citado por NEVES et al, 2014).

As perspectivas de desenvolvimento de Suely são promissoras, com necessidade de trabalho colaborativo entre professores regente, Educação Especial, Artes e Educação Física, visto que os avanços são nítidos, contudo há necessidade de manutenção das conquistas e avanços no desenvolvimento integral de Suely. Esperamos que no próximo ano Suely venha a se desenvolver muito mais a partir do trabalho efetivo que já vem ocorrendo entre instituição de Educação Infantil, família e APAE, através de interações e mediações. O comportamento explosivo, especialmente quando contrariada, ainda carece de atenção e trabalho integrado com a família. Qual será o posicionamento dos profissionais no próximo ano? Qual será a melhor forma de lidar com a situação de aprendizagem de conteúdos da leitura e da escrita e sua resistência em aceitar seus usos?

11 A família adotou, conforme orientações médicas, a restrição a produtos que possuem glúten, lactose e conservantes. Para saber mais: MARCELINO, Claudia. Autismo esperança pela nutrição: histórias de vida, lutas, conquistas e muitos ensinamentos. M Books: São Paulo, 2010. 


\section{Considerações: aplicações para o trabalho pedagógico}

A educação pode ser concebida como um conjunto de recursos, estratégias, metodologias, conteúdos e recursos humanos e que esses, deveriam estar organizados e dispostos a ter novos olhares e práticas sobre o ensinar e o aprender. Contudo, ao longo do período de realização das intervenções e trabalho colaborativo, surgiram vários questionamentos, dentre eles: Como fazer para realizar algumas ações sem o apoio dos demais profissionais? Por que alguns profissionais pensam na criança como um potencial e outros não são capazes de enxergar isso, ou simplesmente não querem ver?

Apesar das barreiras vivenciadas, conseguimos chegar ao final do projeto e obter o resultado esperado. O reconhecimento nos veio através da família, onde a mãe relatou que o desenvolvimento da oralidade da filha é visível e atribui isso ao trabalho com a música realizado no CMEI, juntamente as terapias desenvolvidas na APAE (Associação dos Pais e Amigos dos Excepcionais). A mãe descreveu também, intrigada, que Suely apesar de já estar a um bom tempo nesse espaço formativo e conhecer todos os profissionais, somente é capaz de relatar fatos ocorridos e atribuir nomes a três professores, tia Lu, tia Carla e "tia" Alexandre (sic). Ela ainda não consegue usar a expressão tio. Por mais que a mãe repita, exemplifique, Suely precisa parar e pensar na pessoa citada parecendo não compreender. Um exemplo disso, cita a mãe, foi com a professora do AEE que a atendia no contraturno, Suely não foi capaz de dizer o nome da mesma em nenhum momento. Ressalta-se que o projeto de pesquisa sobre autismo, iniciado no ano de 2015, fez a diferença no desenvolvimento da criança e na vida da família. As parcerias, diálogos e o trabalho interdisciplinar foram fundamentais para que isso acontecesse.

Os aprendizados que podem ser destacados na formação de Suely, ocorridos em 2016, foram o desenvolvimento da linguagem oral, uma vez que capacita o sujeito a interagir com os demais e se apropriar de signos e produzir novos significados; a apropriação dos usos da leitura e da escrita, das capacidades de interação social, de expressão artística e estética e autonomia nas escolhas necessárias no cotidiano da instituição. O trabalho em sala de aula, as brincadeiras, o trabalho com música, as atividades de artes e as experiências de/com o movimento contribuíram para a formação de sua autoimagem, autoconfiança e autoestima, presentes em vários momentos oferecidos pelos diferentes profissionais envolvidos nas práticas pedagógicas trabalhadas no CMEI.

Os conhecimentos sobre o autismo e as possibilidades de desenvolvimento de Suely indicam que o ponto de partida é acreditar nas potencialidades do sujeito, valorizar seus pontos fortes ou áreas fortes e exercer uma tensão contínua entre as barreiras advindas do autismo e as expectativas formativas desejadas, esperadas e planejadas para as crianças nessa faixa etária. Não se trata de projetar um "sujeito ideal", mas mediar os processos de aprendizagem e formação social, aperfeiçoar as capacidades cognitivas, afetivas e sociais a partir da zona de desenvolvimento proximal (VYGOTSKY, 2007).

A educação infantil, como espaço privilegiado de atuação precoce, permite um trabalho articulado e processual, no qual a criança vai se desenvolvendo a partir de vários estímulos. Não se pode atribuir o sucesso das intervenções a apenas um profissional ou a uma atividade pedagógica específica desenvolvida. Todo o progresso narrado até agora pode se considerado fruto dos esforços de professores, assistentes e 
estagiários que atuaram com Suely ao longo de sua permanência na instituição. Trata-se de um processo cumulativo, gradual e complexo que, desde os primeiros dias no CMEI quando se observava seu desenvolvimento e a linguagem oral não ocorria, até o momento do diagnóstico, no qual novos profissionais (agora da Educação Especial) somaram esforços para ampliar as potencialidades de Suely e oferecer o acesso ao currículo vivido na educação infantil. A presença de professores especialistas em Arte e Educação Física qualificam esse trabalho e potencializam a inclusão da criança com deficiência. Há necessidade de um olhar sensível para perceber que o ambiente precisa ser o mais favorável possível para ampliar as possibilidades de desenvolvimento da criança com autismo.

A relação família e profissionais do CMEI foi significativa para o sucesso do desenvolvimento da criança com autismo. Se essa parceria é bem vinda e está indicada nos documentos oficiais (Brasil, 1998 e 2010) para o cotidiano das instituições infantis, quanto mais profícua se faz quando se está lidando com as questões da criança com deficiência. A equipe pedagógica, juntamente com os profissionais envolvidos na educação especial do CMEI organizaram dois encontros com as familias que possuem crianças com deficiência ao longo do ano, para estreitar essas relações e, também, ampliar as possibilidades de desenvolvimento do PAEE.

O trabalho colaborativo tem se mostrado eficaz no processo de inclusão e integração dos sujeitos PAEE. Talvez seja o novo momento da educação inclusiva esse reconhecimento de que a responsabilidade sobre a criança com deficiência não é só da equipe da educação especial, mas pertence a todos os profissionais envolvidos na educação desses sujeitos. Os ganhos estão na capacidade de planejamento articulado, na condução das atividades pedagógicas específicas ou coletivas, na distribuição de tarefas entre os professores e demais profissionais, no acompanhamento pedagógico do processo de aprendizagem de todos as crianças, na troca de experiências e conhecimentos entre os participantes da turma, no esclarecimento das dúvidas sobre a deficiência e a busca de soluções coletivas, no reconhecimento de que a educação é possível para todos. A aprendizagem é possível em um ambiente inclusivo.

As práticas pedagógicas desenvolvidas foram fundamentais para possibilitar um currículo que reconhece o protagonismo infantil. A criança aprende na ação, na relação com a cultura, com as linguagens e na presença do outro. $\mathrm{O}$ autismo e suas características, marcadas pelas ausências, não devem definir o caminho a trilhar nas práticas pedagógicas, mas auxiliar a compreender os comportamentos das crianças com autismo e contribuir para o planejamento de ações efetivas e eficazes que ultrapassam um "possível" limite de aprendizagem. Há sempre o convite a desafiar os sujeitos a seguir mais longe, superar os limites, que às vezes, são impostos antes de se conhecer suas potencialidades. O rótulo não deve dizer o que fazer com e para o sujeito autista, principalmente quando se trata de crianças tão pequenas. Suas possibilidades de desenvolvimento são infinitas, não cabe ao adulto definir o caminho, mas aceitar o convite da criança e trilhar os caminhos que são construídos no dia a dia, no cotidiano das práticas pedagógicas planejadas e vivenciadas pelos e com os sujeitos. 
As relações entre pares nem sempre são benéficas ao processo de constituição do sujeito, cabe ao professor observar essas relações, mediar os conflitos e construir, junto ao grupo, a corresponsabilidade pelo outro. Os comportamentos das crianças no ambiente educacional necessitam estar em consonância com os valores socialmente aceitos, tais como o respeito, a tolerância, a paz, a aceitação da diferença e a responsabilidade pelo mundo em que habitamos. As tensões do dia a dia auxiliam no processo de construção da identidade, mesmo nos momentos de conflitos entre pares há sempre uma formação humana para os envolvidos, desde que os adultos continuem a mediar essas relações, visto que se trata de um espaço de aprendizagens compartilhadas e privilegiado de interação social.

Não poder mudar o vento, no caso do autismo, é reconhecer que esse sujeito possui singularidades que pertencem ao seu modo de ser e estar no mundo. Contudo, ajustar as velas do barco do autismo é traçar novos caminhos e oportunizar viagens inimagináveis; reconhecer que é possível trilhar outros mundos e chegar onde se deseja, com maior qualidade de vida e autonomia do sujeito com autismo. Querer talvez seja o verbo! Desejar pode representar o que nos move como educadores e, com o diz Cortela (s/d) esperançar possibilidades, ou seja, trabalhar para alcançar, lutar e superar desafios dia após dia. Viver cada conquista, viver o presente que é compartilhar a vida com sujeitos tão especiais. Creio que não somos nós que os escolhemos, mas eles que nos escolhem para nos tornarmos pessoas melhores.

\section{Referências}

ARAÚJO, lvaro Cabral; LOTUFO NETO, Francisco. A Nova Classificação Americana Para os Transtornos Mentais - o DSM-5. Revista Brasileira de Terapia Comportamental e Cognitiva, Vol. XVI, n. 1, p. $67-82,2014$.

BALDARES, Maria Jesús V.; OROZCO, Wendy N. Autismo infantil. Revista Cúpula, 26, 2, p. 44-58, 2012.

BAPTISTA, Claudio Roberto; BOSA, Cleonice. Autismo e educação: atuais desafios. In: BAPTISTA, Claudio Roberto; BOSA, Cleonice (org.). Autismo e Educação: reflexões e propostas de intervenção. Porto Alegre: Artmed, 2002.

BRASIL. Ministério da Educação. Diretrizes Curricular Nacional para a Educação Infantil DCNEI. Brasilia: MEC, 2010.

GIL, Antônio Carlos. Como elaborar projetos de pesquisa. Sâo Paulo: Atlas, 1995.

MARTINS, Ligia M. O desenvolvimento do psiquismo e a educação escolar: contribuições à luz da psicologia histórico-cultural e da pedagogia histórico-crítica. Campinas, SP: Autores Associados, 2013.

NEVES, Anderson Jonas das; ANTONELLI, Carolina de Santi; DA SILVA, Mariana Girotto Carvalho; CAPELLINI, Vera Lúcia Messias Fialho. Escolarização formal e dimensões curriculares para alunos 
com autismo: o estado da Arte da produção acadêmica brasileira. Educação em Revista|Belo Horizonte | v.30|n.02|p.43-70| Abril-Junho 2014.

ORRÚ, Sílvia Ester. Contribuições da abordagem histórico-cultural na educação de alunos autistas. Revista Humanidades Médicas, SEP-Dic, vol. 10, n. 3, 2010.

PADILHA, Anna Maria Lunardi. Possibilidades de histórias ao contrário, ou, como desencaminhar o aluno da classe especial. 3. ed. rev. e ampl. São Paulo: Plexus, 2004.

PAIVA JUNIOR. Casos de autismo sobem para 1 a cada 68 crianças. Revista Autismo, 03/2014. Disponível em: http://www.revistaautismo.com.br/noticias/casos-de-autismo-sobem-para-1-a-cada-68criancas. Acesso em: 31/12/2015.

PALACIOS, J.; MARCHESI, A. Desenvolvimento psicológico e educação: necessidades educativas especiais e aprendizagem escolar. Porto Alegre: Artes Médicas, 1995.

PALLARÈS, Josep Artigas; PAULA, Isabel. El autismo 70 años después de Leo Kanner y Hans Asperger. Rev. Asoc. Esp. Neuropsiq., n. 32 (115), p. 567-587, 2012.

PASQUALINI,Juliana Campregher. O papel do professor e do ensino a Educação Infantil: a perspectiva de Vigotski, Leontiev e Elkonin. In: DUARTE, Newton; MARTINS, Lígia Márcia (orgs.). Formação de professores: limites contemporâneos e alternativas. São Paulo: Cultura Acadêmica, 2010.

RIVIÈRE, Angel. O desenvolvimento e a educação da criança autista. (Org.) COLL, C.;

VASQUES, Carla K. Alice na biblioteca mágica: uma leitura sobre o diagnóstico e a escolarização de crianças com autismo e psicose infantil. Tese de doutorado. UFRGS/PPGE, Porto Alegre: 2008.

VENTURA, Magda Maria. O Estudo de Caso como Modalidade de Pesquisa. Revista SOCERJ. 20(5), set./out., p. 383-386, 2007.

VYGOTSKY, Lev S. A formação social da mente: o desenvolvimento dos processos psicológicos superiores; organizadores Michael Cole... [et al.]. 7. ed. São Paulo: Martins Fontes, 2007.

VYGOTSKY, Lev S. Pensamento e linguagem. Trad. Jefferson Luiz Camargo. São Paulo: Martins Fontes, 2005.

VYGOTSKY, Lev S.; LURIA, A.R.; LEONTIEV, A.N. Linguagem, Desenvolvimento e Aprendizagem. $10^{\mathrm{a}}$ ed. São Paulo: Ícone, 2006. 